\title{
The Use of Prophylaxis Antibiotics to Prevent Acute Pancreatitis Complications: Meta-Analysis of Clinical Trials
}

\author{
Dwita Nitoya Esterini*, Kirsten Putriani Hartman*, Joue Abraham Trixie*, \\ Yessi Setianegari*, Kurniyanto** \\ *Faculty of Medicine, Christian University of Indonesia, Jakarta \\ **Department of Internal Medicine, Faculty of Medicine, Christian University of Indonesia, Jakarta
}

\section{Corresponding author:}

Kurniyanto. Department of Internal Medicine, Faculty of Medicine, Christian University. Jl. Mayjen Sutoyo No. 2 Jakarta Indonesia. Phone/facsimile: +62-21-8092425.E-mail: Kurniyanto@outlook.com

\section{ABSTRACT}

Background: Acute pancreatitis (AP) is an inflammation of the pancreas, a serious emergency with no definitive treatment. It may progress to infected necrosis, non-pancreatitis infection, also death that may occur within the first 1 to 2 weeks. The use of prophylactic antibiotics in AP to prevent complications remains a controversy. The objective of this meta-analysis is to assess the benefit of prophylaxis antibiotics administration to prevent the complication.

Method: Trials were identified by searching the medical database. Literature range is within the year 1975 to 2021. Review Manager 5.4.1 was used to analyse data extraction and risk of bias of included studies were elaborated. Risk ratio (RR) was calculated with $95 \%$ confidence interval (CI). $P<0.05$ was considered significant.

Results: Twenty trials with a total of 1.287 patients of AP were analysed; 646 patients treated with antibiotic prophylaxis and 641 patients treated with placebo. Prophylaxis antibiotics were found to have significant difference between the two groups. The administration of prophylaxis antibiotics lower the risk of non-pancreatic infections $(R R=0.77 ; 95 \% C I: 0.62-0.95 ; p<0.05)$ and infected pancreatic necrosis $(R R=0.74 ; 95 \%$ CI: 0.58-0.94; $p$ $<0.05)$. Meanwhile, prophylaxis antibiotics were found to be insignificant to lower the risk of mortality $(R R=$ 0.75; 95\% CI: 0.54-1.03; $p>0.05$ ).

Conclusion: Prophylaxis antibiotics lower the risk of non-pancreatic infections and infected pancreatic necrosis, but did not lower the risk of mortality.

Keywords: acute pancreatitis, antibiotic prophylaxis, clinical trial, mortality

\begin{abstract}
ABSTRAK
Latar belakang: Pankreatitis Akut (PA) adalah inflamasi pada pancreas, kondisi emergensi tanpa pengobatan definitive. Hal ini dapat berkembang menjadi nekrosis yang terinfeksi, infeksi non-pankreatitis, juga kematian yang terjadi dalam satu sampai dua minggu pertama. Penggunaan antibiotic sebagai profilaksis terhadap PA dalam mencegah terjadinya komplikasi masih kontroversi. Tujuan dari meta-analisis ini adalah untuk menilai keuntungan pemberian profilaksis antibiotic dalam mencegah terjadinya komplikasi.

Metode: Pencarian uji klinis melalui database medis. Rentang literature antara tahun 1975 sampai 2021. Review Manager 5.4.1 digunakan dalam menganalisa data yang diesktraksi dan risiko bias dari studi yang dilibatkan. Risiko rasio (RR) dihitung dengan interval kepercayaan 95\% CI. Nilai $p<0.05$ dianggap signifikan.
\end{abstract}


Hasil: Dua puluh uji klinis dengan total 1.287 pasien dari PA dianalisa; 646 pasien diberikan profilaksis antibiotik dan 641 pasien diberikan placebo. Profilaksis antibiotik menunjukkan hasil yang signifikan pada kedua grup. Pemberian profilaksis antibiotic menurunkan risiko dari infeksi non-pankreatitis $(R R=0.77 ; 95 \%$ CI: $0.62-0.95 ; p<0.05)$ dan nekrosis pancreas yang terinfeksi $(R R=0.74 ; 95 \%$ CI: 0.58-0.94; $p<0.05)$. Sementara itu, profilaksis antibiotic menunjukkan hasil yang tidak signifikan dalam menurunkan risiko dari kematian $(R R=0.75 ; 95 \%$ CI: 0.54-1.03; $p>0.05)$.

Simpulan: Profilaksis antibiotik menurunkan risiko infeksi non-pankreas dan nekrosis pankreas yang terinfeksi, tetapi tidak menurunkan risiko kematian.

Kata kunci: pankreatitis akut, profilaksis antibiotik, uji klinis, mortalitas

\section{INTRODUCTION}

Acute pancreatitis (AP) is a condition in which the pancreas becomes inflamed in a short period of time. The most common causes of AP are blockage from gallstones and excessive alcohol consumption. ${ }^{1,2} \mathrm{AP}$ is the leading cause of hospitalization in the United States. ${ }^{3}$ Annually, the disease has an incidence of approximately 40 to 50 cases per 100,000 adults. ${ }^{1,4}$ The disease usually has a poor prognosis. Death at the beginning of newly diagnosed pancreatitis occurs in half of patients within the first 14 days, due to the failure of various organ systems. The remaining causes of death are related to secondary infection from necrotic pancreas. ${ }^{4}$ Supported by research conducted by Fu et al (2007), about half of pancreatitis patients die within 14 days due to multiple organ system failure. $^{5}$

The management of pancreatitis is adjusted to the existing phases of pancreatitis, namely acute, necrotic, and infected. ${ }^{2}$ Therapies given to patients with pancreatitis, both acute and chronic, are rehydration, low-fat diet, analgesics, and administration of antibiotics; all of which requires hospitalisation for easier management. ${ }^{6,7}$ Within 72 hours of acute pain attack, necrosis begins to occur. It is important to give antibiotics as prophylaxis once acute pancreatitis is diagnosed, because after the necrosis phase is the infection phase. Infection often occurs after a week of the initial attack, so it is preferable to give prophylactic antibiotics for two weeks. ${ }^{2}$ However, antibiotics as prophylaxis drugs is still a controversy. ${ }^{8}$

This meta-analysis aims to assess the benefits of administering antibiotics as prophylaxis in preventing the occurrence of infected pancreatic necrosis, nonpancreatitis infection, and death/mortality due to acute pancreatitis.

\section{METHOD}

A systematic literature search was conducted independently by the three authors, using medical search engines, such as Pubmed, Science Direct, and The Cochrane Library, and medical journals, one of which is the Annals of Gastroenterology. The range of literature sought is until the year of 2021. The literature search is limited to human studies and published in Indonesian or English. The keywords used for the study were "acute pancreatitis," "antibiotic prophylaxis," "pancreatitis," "prophylactic antibiotics," and "controlled trials." After gathering relevant studies, full-text articles were analysed. Eligible studies were then included in the meta-analysis.

The inclusion criteria used were: (1) clinical trials comparing prophylactic antibiotics with placebo/other supportive treatment; (2) study population of patients with a diagnosis of severe acute pancreatitis with clinical diagnosis (scoring system or criteria), as well as supporting examinations; (3) researches using English or Indonesian language. Meanwhile, the exclusion criteria were: (1) study design in the form of cohort, case control, and literature review; (2) languages that the authors are not proficient in; (3) comparison used in clinical trials that are not placebo or supportive therapies.

Jadad scale was used to assess the quality of the study, in which it consists of five points; randomization, appropriate randomization, double blind, blind appropriate, and description of withdrawal and drop out. Each question is worth one point. If three to five questions have a "yes" answer, then it is worth 3-5. Studies within this range of scores are considered of good quality. If the score is $1-2$, the study is considered of poor quality, so it is not included in the data analysis. ${ }^{10}$ Review manager application 5.4.1 was used to process the data. Risk ratio (RR) was calculated with $95 \%$ confidence interval $(\mathrm{CI}) . \mathrm{P}<0.05$ was considered significant. 


\section{RESULTS}

Table 1 shows characteristics of all the studies included in this meta-analysis. Figure 1 show the selection of studies. We analysed 20 clinical trials with a total of 1,287 patients. It was divided into two groups; a group of 646 patients treated with antibiotic prophylaxis and a group of 641 patients treated with placebo.

The results of data analysis shows that prophylactic antibiotics were shown to reduce the risk of non pancreatic infection $(\mathrm{RR}=0.77 ; 95 \% \mathrm{CI}=0.62-0.95$; $\mathrm{p}<0.05$ ) (Figure 2) and infected pancreatic necrosis $(\mathrm{RR}=0.74 ; 95 \%$ CI: 0.58-0.94; $\mathrm{p}<0.05)$ (Figure 3). Meanwhile, prophylactic antibiotics did not reduce the risk of mortality ( $\mathrm{RR}=0.75$; $95 \% \mathrm{CI}$ : $0.54-1.03$; $p>0.05$ ) (Figure 4). The results of this analysis were also supported by the quality of each study which was individually assessed with a Jadad scale. The studies included also had a low risk of bias (as shown in Figure 5 and Figure 6).

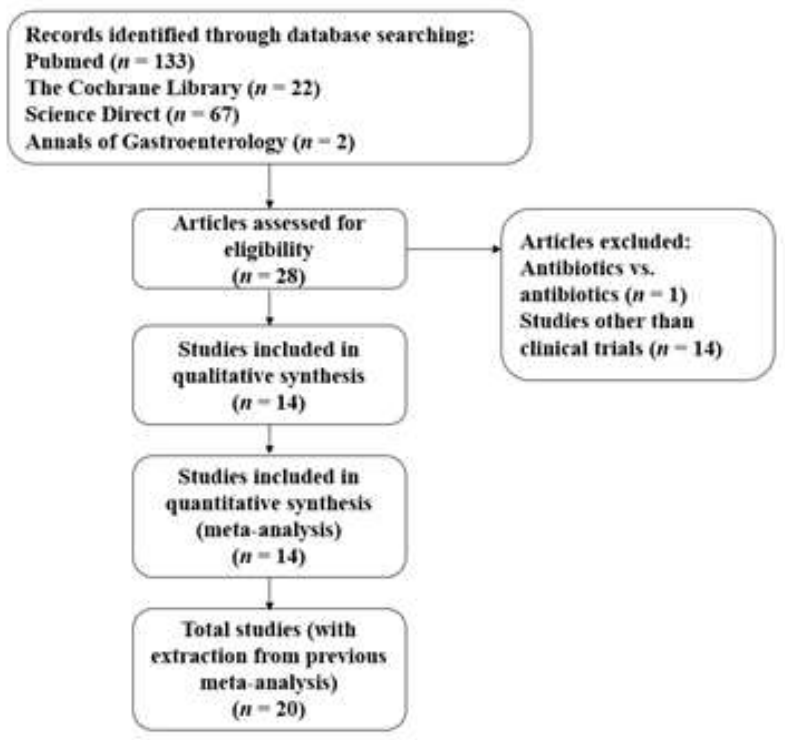

Figure 1. Flowchart of the study

Table 1. Characteristics of the studies

\begin{tabular}{|c|c|c|c|c|}
\hline Author & Year & Country & Population characteristics & Antibiotics \\
\hline Pederzoli & 1993 & Italy & $\begin{array}{c}74 \text { subjects with } 41 \text { receiving prophylactic antibiotics and } \\
33 \text { without prophylactic antibiotics }\end{array}$ & Imipenem \\
\hline Sainio & 1995 & Finland & $\begin{array}{c}60 \text { subjects with } 30 \text { receiving prophylactic antibiotics and } \\
30 \text { without prophylactic antibiotics }\end{array}$ & Cefuroxime \\
\hline Delcenserie & 1996 & France & $\begin{array}{l}23 \text { subjects with } 11 \text { receiving prophylactic antibiotics and } \\
\qquad 12 \text { without prophylactic antibiotics }\end{array}$ & $\begin{array}{l}\text { Ceftazidime + Amikacin + } \\
\quad \text { Metronidazole }\end{array}$ \\
\hline Schwarz & 1997 & German & $\begin{array}{c}26 \text { subjects with } 13 \text { receiving prophylactic antibiotics and } \\
13 \text { without prophylactic antibiotics }\end{array}$ & Ofloxacin + Metronidazole \\
\hline Nordback & 2001 & Finland & $\begin{array}{c}58 \text { subjects with } 25 \text { receiving prophylactic antibiotics and } \\
\qquad 33 \text { without prophylactic antibiotics }\end{array}$ & Imipenem \\
\hline Spicak & 2002 & Czech & $\begin{array}{c}63 \text { subjects with } 33 \text { receiving prophylactic antibiotics and } \\
30 \text { without prophylactic antibiotics }\end{array}$ & $\begin{array}{l}\text { Ciprofloxacin + } \\
\text { Metronidazole }\end{array}$ \\
\hline Spicak & 2003 & Czech & $\begin{array}{l}41 \text { subjects with } 20 \text { receiving prophylactic antibiotics and } \\
21 \text { without prophylactic antibiotics }\end{array}$ & Meropenem \\
\hline Isenmann & 2004 & German & $\begin{array}{c}114 \text { subjects with } 58 \text { receiving prophylactic antibiotics } \\
\text { and } 56 \text { without prophylactic antibiotics }\end{array}$ & $\begin{array}{l}\text { Ciprofloxacin + } \\
\text { Metronidazole }\end{array}$ \\
\hline Røkke & 2007 & Norway & $\begin{array}{c}73 \text { subjects with } 36 \text { receiving prophylactic antibiotics and } \\
37 \text { without prophylactic antibiotics }\end{array}$ & Imipenem \\
\hline Dellinger & 2007 & $\begin{array}{l}\text { North America } \\
\text { and Europe }\end{array}$ & $\begin{array}{c}100 \text { subjects with } 50 \text { receiving prophylactic antibiotics } \\
\text { and } 50 \text { without prophylactic antibiotics }\end{array}$ & Meropenem \\
\hline Barreda & 2009 & Perú & $\begin{array}{c}58 \text { subjects with } 24 \text { receiving prophylactic antibiotics and } \\
34 \text { without prophylactic antibiotics }\end{array}$ & Imipenem \\
\hline Garcia-Barrasa & 2009 & Spain & $\begin{array}{c}41 \text { subjects with } 22 \text { receiving prophylactic antibiotics and } \\
19 \text { without prophylactic antibiotics }\end{array}$ & $\begin{array}{l}\text { Ciprofloxacin + } \\
\text { Metronidazole }\end{array}$ \\
\hline Xue & 2009 & China & $\begin{array}{l}56 \text { subjects with } 29 \text { receiving prophylactic antibiotics and } \\
27 \text { without prophylactic antibiotics }\end{array}$ & Imipenem \\
\hline Yang & 2009 & China & $\begin{array}{l}54 \text { subjects with } 28 \text { receiving prophylactic antibiotics and } \\
\qquad 26 \text { without prophylactic antibiotics }\end{array}$ & Imipenem \\
\hline Poropat & 2016 & Croatia & $\begin{array}{c}47 \text { subjects with } 23 \text { receiving prophylactic antibiotics and } \\
24 \text { without prophylactic antibiotics }\end{array}$ & Imipenem \\
\hline Poropat & 2017 & Croatia & $\begin{array}{c}98 \text { subjects with } 49 \text { receiving prophylactic antibiotics and } \\
49 \text { without prophylactic antibiotics }\end{array}$ & Imipenem \\
\hline Howes & 1975 & United States & $\begin{array}{l}95 \text { subjects with } 48 \text { receiving prophylactic antibiotics and } \\
47 \text { without prophylactic antibiotics }\end{array}$ & Ampicillin \\
\hline Craig & 1975 & Australia & $\begin{array}{l}46 \text { subjects with } 23 \text { receiving prophylactic antibiotics and } \\
23 \text { without prophylactic antibiotics }\end{array}$ & Ampicillin \\
\hline Finch & 1976 & United States & $\begin{array}{c}58 \text { subjects with } 31 \text { receiving prophylactic antibiotics and } \\
27 \text { without prophylactic antibiotics }\end{array}$ & Ampicillin \\
\hline Luiten & 1995 & Netherlands & $\begin{array}{c}102 \text { subjects with } 52 \text { receiving prophylactic antibiotics } \\
\text { and } 50 \text { without prophylactic antibiotics }\end{array}$ & $\begin{array}{l}\text { SD (Collitin + amphotericin } \\
+ \text { narfloxacin) + cefotaxime }\end{array}$ \\
\hline
\end{tabular}




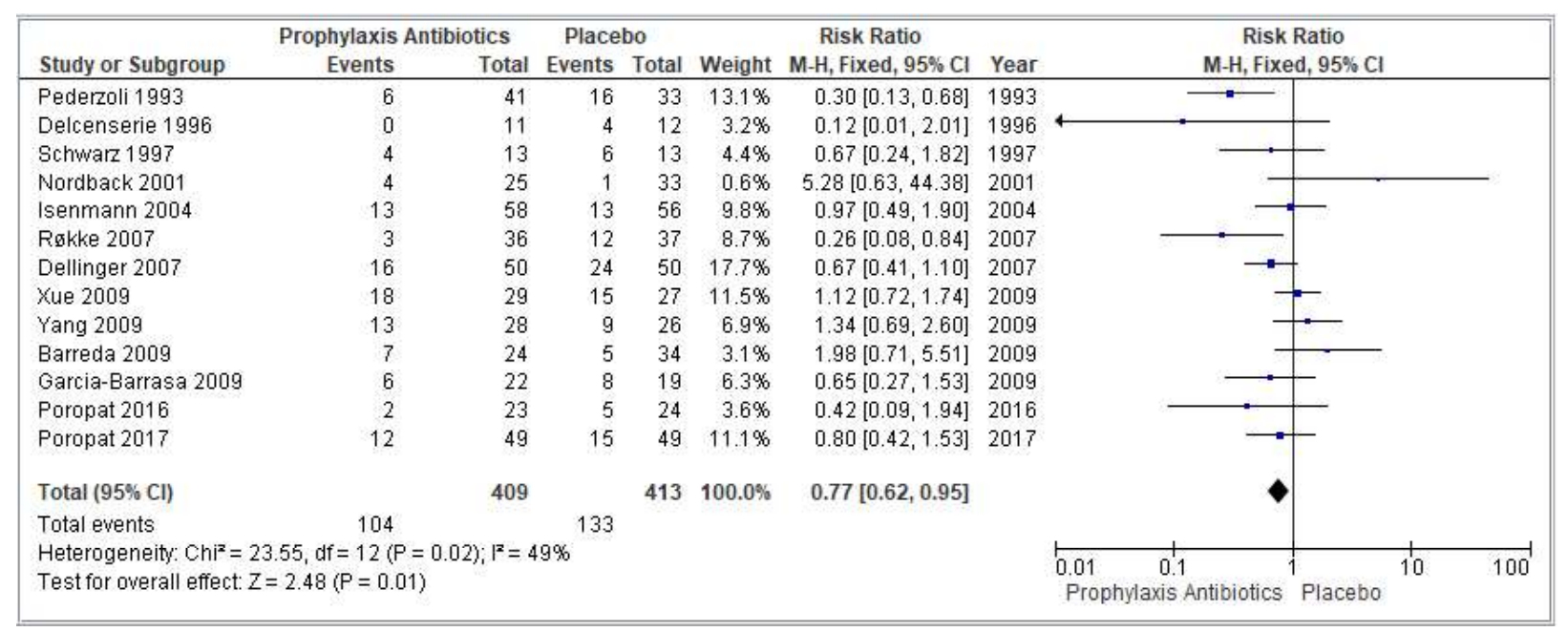

Figure 2. Forrest plot analysis of non pancreatic infection

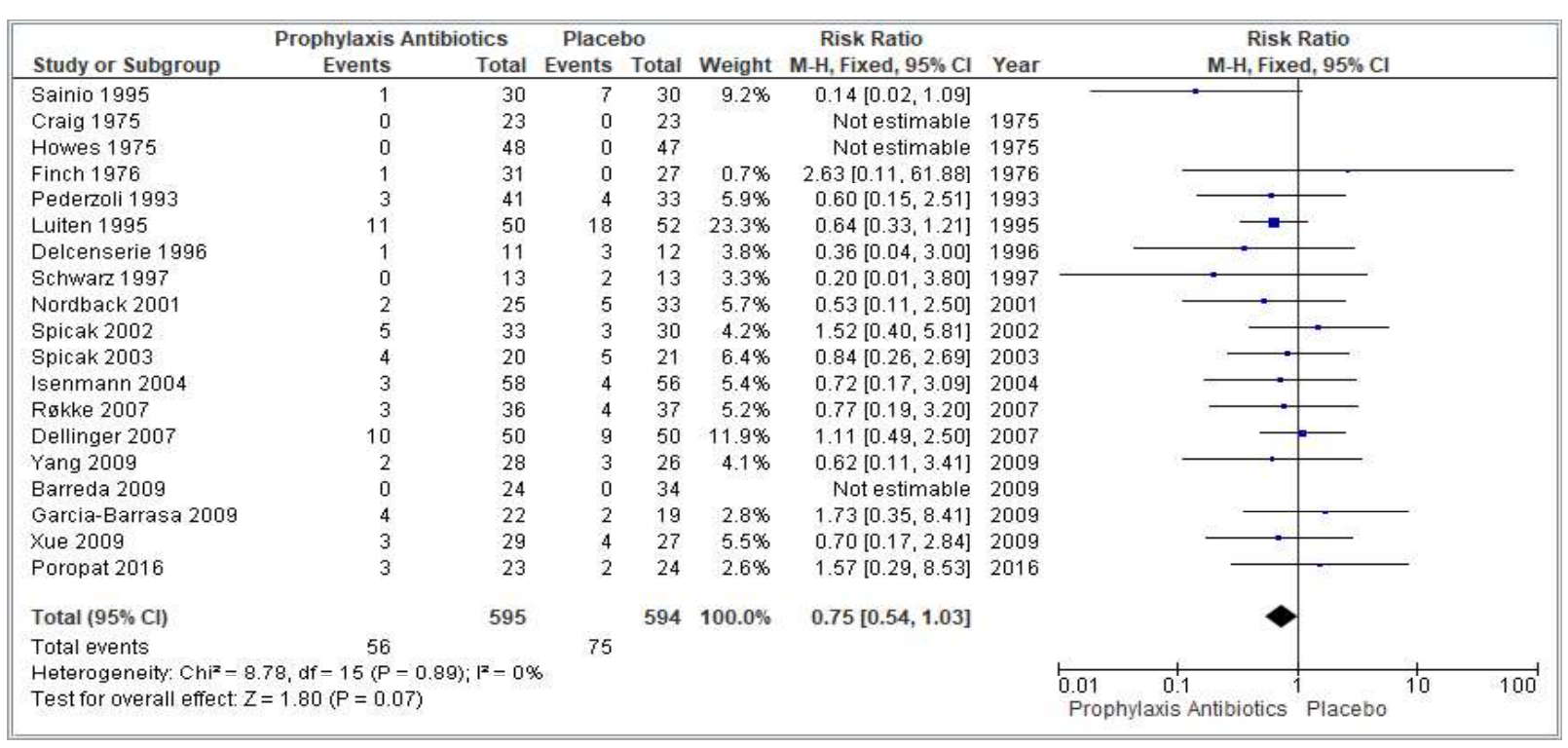

Figure 3. Forrest plot analysis of infected pancreatic necrosis

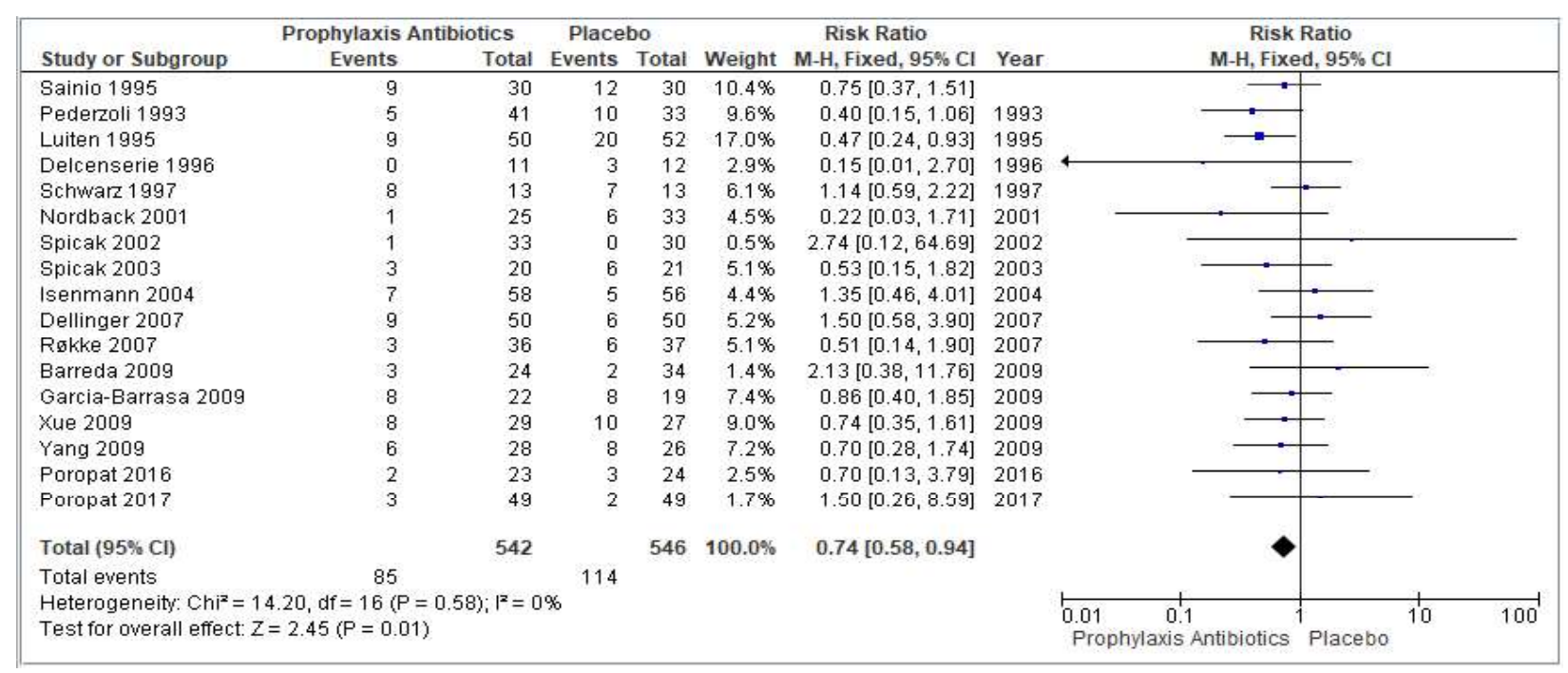

Figure 4. Forrest plot analysis of mortality 


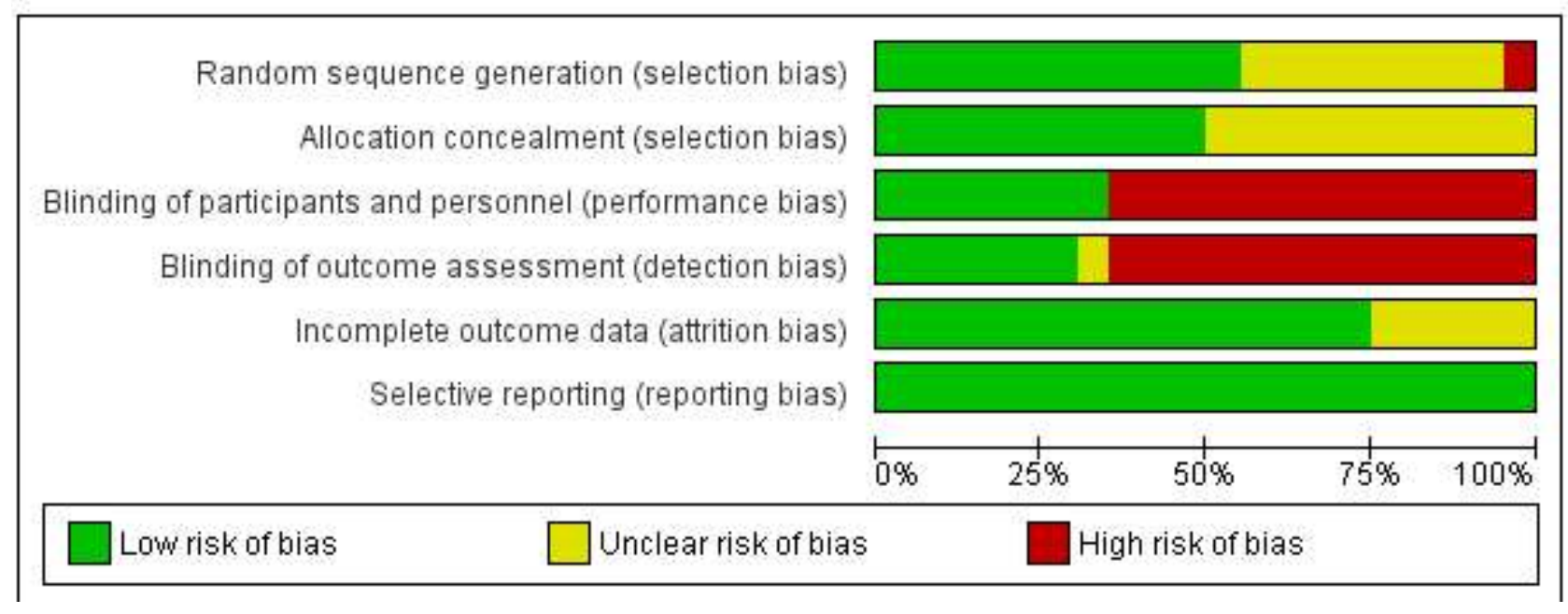

Figure 5. Risk of bias graph

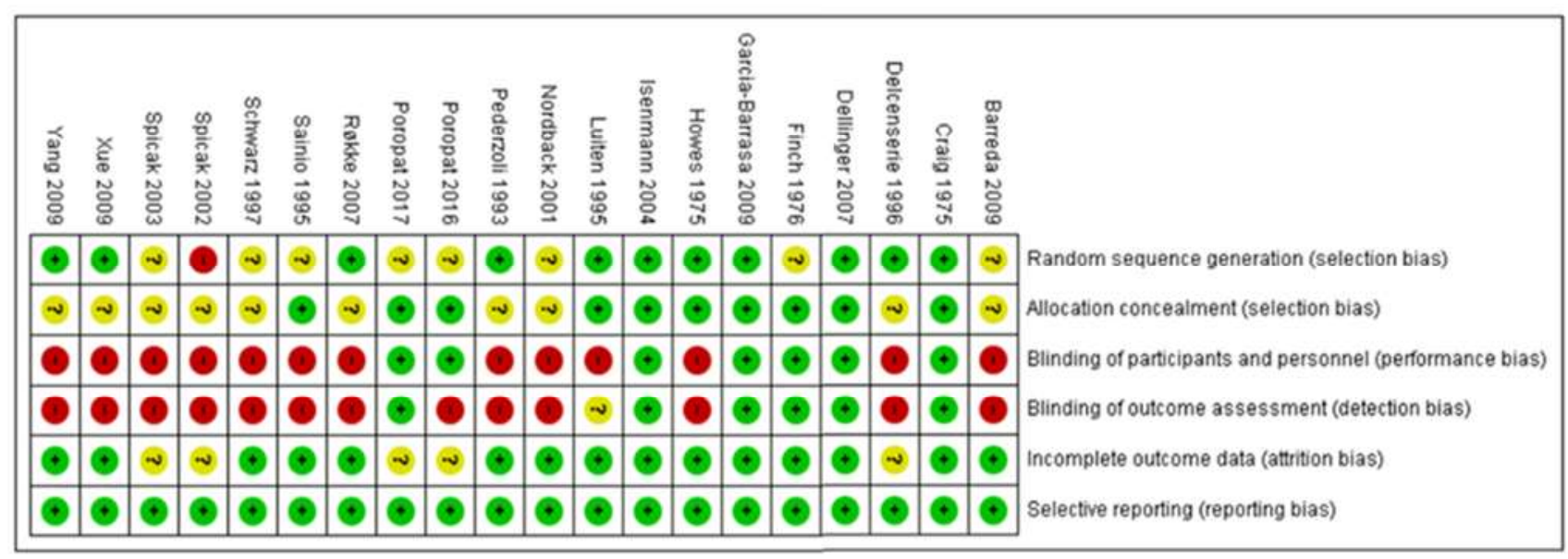

Figure 6. Risk of bias summary

\section{DISCUSSION}

The results of data analysis showed that prophylactic administration of antibiotics in patients with acute pancreatitis can reduce the risk of non-pancreatic infections and infected pancreatic necrosis, but not mortality. The results of this data analysis have differences and similarities with several guidelines.

Greenberg et al (2016) from the University of Toronto do not recommended antibiotic prophylaxis in pancreatitis. Antibiotics are only given in cases where infected necrosis has occurred as evidenced by a biopsy or gas accumulation in CT scan results. Therefore, the administration of antibiotics here is not as prophylaxis, but as therapy. In this guideline, antibiotics are given based on culture results. ${ }^{10}$ This guideline is based on a meta-analysis in 2008, 2010, 2011, and 2012 which stated that there was no significant difference between the groups receiving antibiotics as prophylaxis and placebo in mortality, incidence of infected pancreatic necrosis, and the incidence of non-pancreatic infection. ${ }^{11,12,13,14}$
Another meta-analysis compiled by Nan et al (2020), consisting of 11 clinical trials, stated that prophylactic antibiotics in cases of AP can reduce the risk of non-pancreatic infection $(\mathrm{OR}=0.59 ; 95 \%$ CI: $0.42-0.84 ; p=0.004)$. However, it is not the case with infected pancreatic necrosis $(\mathrm{OR}=0.74 ; 95 \% \mathrm{CI}$ : $0.50-1.09 ; \mathrm{p}=0.13)$ and mortality $(\mathrm{OR}=0.71 ; 95 \%$ CI: $0.44-1.15 ; \mathrm{p}=0.16) .{ }^{15}$

Of the five meta-analyses that were compared, this meta-analysis indicates the same results, namely the administration of antibiotics in cases of AP had no impact on mortality. However, the administration of antibiotics as prophylaxis can reduce the risk of nonpancreatic infection and infected pancreatic necrosis.

There are several guidelines regarding the management of AP. The first guideline was the American College of Gastroenterology (ACG) in 2013. This guideline recommends the use of antibiotics as prophylaxis in cases of severe acute pancreatitis and/ or sterile necrosis. However, intervention in patients with infected necrosis may be delayed through the use 
of antibiotics that do not penetrate the necrotic tissue. No examples of antibiotics used are mentioned. ${ }^{16}$

The American Gastroenterological Association (AGA) also issued a guideline in the year 2018. This guideline states that in patients with a prediction of severe acute pancreatitis and necrotizing acute pancreatitis, it is recommended to use antibiotics as prophylaxis. $^{17}$

Finally, the latest guideline from the World Society of Emergency Surgery (WSES) in 2019 states that prophylactic administration of antibiotics in patients with AP was not associated with a significant reduction of mortality or morbidity. ${ }^{18}$

Regardless of prior studies' findings, antibiotics may still be used in treating AP. In patients with infected necrosis, antibiotics that are able to penetrate pancreatic necrosis should be used. Furthermore, in patients with infected necrosis, the spectrum of empirical antibiotic regimen should include both aerobic and anaerobic Gram-negative and Grampositive microorganisms. ${ }^{18}$

In the standard intravenous dosages, aminoglycoside antibiotics (such as gentamicin and tobramycin) are ineffective to penetrate into the pancreas in sufficient tissue concentrations to cover the minimal inhibitory concentration (MIC) of the bacteria that are commonly found in secondary pancreatic infections. ${ }^{19}$

Unlike with gentamicin and tobramycin, acylureidopenicillins and third-generation cephalosporins have an intermediate penetration into pancreas tissue and are effective against Gramnegative microorganisms. They can cover the MIC for most Gram-negative organisms found in pancreatic infections..$^{20}$ Amongst these antibiotics, only piperacillin/tazobactam is effective against Grampositive bacteria and anaerobes. ${ }^{18}$

Quinolones (ciprofloxacin and moxifloxacin) and carbapenems both show good tissue penetration into the pancreas, with the additional benefit of excellent anaerobic coverage..$^{20-24}$ However, because of quinolones' high rate of resistance worldwide, quinolones are not recommended and are used only in patients allergic to beta-lactam agents. Due to the spread of carbapenem resistancy to Klebsiella pneumoniae, carbapenems should be used only in very critically ill patients. ${ }^{18}$

With its function as a bactericidal, metronidazole is almost exclusively focused against anaerobes, and is able to penetrate into the pancreas. ${ }^{18}$

Pathogenesis of secondary bacterial pancreatic infection is still in debate. Pathogens can reach the pancreas through the hematogenous pathway, via the biliary system, ascending from the duodenum via the main pancreatic duct, or through transmural colonic migration via translocation of the colonic bacteria. ${ }^{18,25}$

Most pathogens in pancreatic infection are gastrointestinal Gram-negative bacteria (Escherichia coli, Proteus, Klebsiella pneumonia), which occur via disruption of the intestinal flora and damage to the bowel mucosa. Impaired body defenses predispose to translocation of the gastrointestinal organisms and toxins with subsequent secondary pancreatic infection. However, Gram-positive bacteria (Staphylococcus aureus, Streptococcus faecalis, Enterococcus), anaerobes, and, occasionally, fungi have also been found..$^{18,26}$

\section{CONCLUSION}

In conclusion, prophylaxis antibiotics lower the risk of non-pancreatic infections and infected pancreatic necrosis, but did not lower the risk of mortality. Therefore, due to our limitation in this meta-analysis further studies re needed to based on antibiotic type.

\section{REFERENCES}

1. Acute Pancreatitis [serial online]. NHS. 2021 [cited 2021 October 21]. Available from: https://www.nhs.uk/conditions/ acute-pancreatitis/

2. Sjamsuhidajat R, de Jong. Buku Ajar Ilmu Bedah Volume 2. In: Bustami ZS, Rendy L, Nugroho AW, eds. Jakarta: EGC; 2017

3. Gapp J, Chandra S. Acute Pancreatitis. In: StatPearls [serial online] [cited 2021 June 26] Treasure Island (FL): StatPearls Publishing; 2021. Available from: https://www.ncbi.nlm.nih. gov/books/NBK482468/

4. In Acute Pancreatitis Is It an Early or a Late Event? [serial online]. Pancreas Imedpub. 2021 [cited 21 October 2021]. Available from: https://pancreas.imedpub.com/mortality-inacute-pancreatitis-is-it-an-early-or-a-late-event.php?aid=3127

5. Fu CY, Yeh CN, Hsu JT, Jan YY, Hwang TL. Timing of mortality in severe acute pancreatitis: experience from 643 patients. World J Gastroenterol 2007;13:1966-69.

6. Treatment for Pancreatitis [serial online]. NIH NIDDK. 2020 [Cited 21 October 2021]. Available from: https://www.niddk. nih.gov/health-information/digestive-diseases/pancreatitis/ treatment

7. Tenner S, Baillie J, DeWitt J, Vege SS. American College of Gastroenterology. American College of Gastroenterology guideline: management of acute pancreatitis. Am J Gastroenterol 2013;108:1400-15;1416.

8. Tang J C F, Markus J T, Anand B S. Acute Pancreatitis [serial online]. Medscape. 2021 [Cited 2021 October 21]. Available: https://emedicine.medscape.com/article/181364-overview.

9. Berger VW, Alperson SY. A general framework for the evaluation of clinical trial quality. Rev Recent Clin Trials 2009;4:79-88.

10. Greenberg JA, Hsu J, Bawazeer M, Marshall J, Friedrich JO, 
Nathens A, et al. Clinical practice guideline: management of acute pancreatitis. Can J Surg 2016;59:128-40.

11. Bai Y, Gao J, Zou DW, Li ZS. Prophylactic antibiotics cannot reduce infected pancreatic necrosis and mortality in acute necrotizing pancreatitis: evidence from a metaanalysis of randomized controlled trials. Am J Gastroenterol 2008;103:104-10.

12. Villatoro E, Mulla M, Larvin M. Antibiotic therapy for prophylaxis against infection of pancreatic necrosis in acute pancreatitis. Cochrane Database Syst Rev 2010;5:CD002941.

13. Jiang K, Huang W, Yang XN, Xia Q. Present and future of prophylactic antibiotics for severe acute pancreatitis. World J Gastroenterol 2012;18:279-84.

14. Wittau M, Mayer B, Scheele J, Bruns DH, Dellinger EP, Isenmann R, et al. Systematic review and meta-analysis of antibiotic prophylaxis in severe acute pancreatitis. Scand J Gastroenterol 2011;46:261-70.

15. Ding N, Sun YH, Wen LM, Wang JH, Yang JH, Cheng K, et al. Assessment of prophylactic antibiotics administration for acute pancreatitis: a meta-analysis of randomized controlled trials. Chin Med J (Engl) 2020;133:212-20.

16. Tenner S, Baillie J, DeWitt J, Vege SS. American College of Gastroenterology. American College of Gastroenterology guideline: management of acute pancreatitis. Am J Gastroenterol 2013;108:1400-15;1416.

17. Vege SS, Ziring B, Jain R, Moayyedi P. Clinical Guidelines Committee; American Gastroenterology Association. American gastroenterological association institute guideline on the diagnosis and management of asymptomatic neoplastic pancreatic cysts. Gastroenterology 2015;148:819-22.

18. Leppäniemi A, Tolonen M, Tarasconi A, Lohse HS, Gamberini E, Kirkpatrick AW, et al. 2019 WSES guidelines for the management of severe acute pancreatitis. World J Emerg Surg 2019;14:27.

19. Buchler M, Malfertheiner P, Friess H, Isenmann R, Vanek E, Grimm $\mathrm{H}$, et al. Human pancreatic tissue concentration of bactericidal antibiotics. Gastroenterology 1992;103:1902-8.

20. Otto W, Komorzycki K, Krawczyk M. Efficacy of antibiotic penetration into pancreatic necrosis. HPB Oxford 2006;8:43-8.

21. Brattström C, Malmborg AS, Tyden G. Penetration of imipenem into human pancreatic juice following single intravenous dose administration. Chemotherapy 1989;35:83-7.

22. Wittau M, Wagner E, Kaever V, Koal T, Henne-Bruns $\mathrm{D}$, Isenmann $\mathrm{R}$, et al. Intraabdominal tissue concentration of ertapenem. J Antimicrob Chemother 2006;57:312-6.

23. Wacke R, Forster S, Adam U, Mundkowski RG, Klar E, Hopt UT, et al. Penetration of moxifloxacin into the human pancreas following a single intravenous or oral dose. J Antimicrob Chemother 2006;58:994-9.

24. Schubert S, Dalhoff A. Activity of moxifloxacin, imipenem, and ertapenem against Escherichia coli, Enterobacter cloacae, Enterococcus faecalis, and Bacteroides fragilis in monocultures and mixed cultures in an in vitro pharmacokinetic/pharmacodynamic model simulating concentrations in the human pancreas. Antimicrob Agents Chemother 2012;56:6434-6.

25. Mourad MM, Evans R, Kalidindi V, Navaratnam R, Dvorkin L, Bramhall SR. Prophylactic antibiotics in acute pancreatitis: endless debate. Ann R Coll Surg Engl 2017;99:107-12.

26. Reuken PA, Albig H, Rödel J, Hocke M, Will U, Stallmach $A$, et al. Fungal infections in patients with infected pancreatic necrosis and pseudocysts: risk factors and outcome. Pancreas 2018;47:92-8. 